\title{
THE INTERPRETATIONS OF THE WORD "WOMAN" IN CHINESE LANGUAGE (BASED ON AN UNSUCCESSFUL INTERCULTURAL COMMUNICATION CASE ANALYSIS)
}

\author{
Liu Chaojie, Zhong Weiliang
}

\author{
Zhejiang Ocean University, Zhoushan, China
}

\begin{abstract}
Introduction. It is well acknowledged that communication is a behavior process, which aims to help different behavior agents to achieve two-way information flow through a variety of carriers, to form the perception of the behavior agents, and to achieve a specific goal. Communication can bring people together, but cultural differences keep them apart. People quite often ignore social and cultural factors in intercultural communication, which could bring about the consequence of communication breakdown.

Aim and objectives. Define interpretations of the word "woman" in the Chinese language.

Material and methods. Abundant theoretical works on intercultural communication are profoundly used which have laid solid foundation for the interpretations of basic concept. Meanwhile, many Chinese and English explanatory dictionaries are used to interpret the semantic meaning of the word "woman". By means of case analysis, the article discovers the semantic differences of word "woman" in Chinese language and Russian language and points out the negative attitude of Chinese students towards the semantic meaning of word "women". Furthermore, researches are conducted among the exchange students from Zhejiang Ocean University in order to discover the hidden reasons, which have caused negative attitude towards the semantic meaning of word "women".

Results and discussion. Based on the analysis of an unsuccessful intercultural communication experience of exchange students from China, the article explicitly reveals the semantic meanings including the extended meaning and the figurative meaning of the word "woman" in the Chinese language context, and explores the roots of the formation of the existing cognitive semantic meanings.

Conclusion. Globalization inevitably influences the concept and ideology of the whole world. At present, China has entered a cultural transition period, when modern culture must take the place of traditional culture, and the national culture faces the challenge and invasion of foreign culture.
\end{abstract}

Keywords: culture, cultural differences, intercultural communication, the word "woman", semantic meanings.

\section{Culture and Intercultural Communication}

One of the most important reasons for studying intercultural communication is that it raises the awareness of our own cultural identity and background. This is also one of the least obvious reasons. However, it is important to recognize that intercultural learning is not always easy or comfortable [1]. For intercultural communication studies to be meaningful in an increasingly interconnected world, to be theoretically sound and to be socially relevant, researchers usually eschew a priori definitions of culture. A priori assumptions about 'culture' are clearly absent from studies in the interdiscourse tradition, and from many studies in the intercultural communication tradition [2].

In 1952, Alfred Kroeber and Clyde Kluckhohn compiled a list of 164 definitions of 'culture'. More than six decades have passed, and during this time, a new academic field, cultural studies, has burgeoned and interest in and debates around culture have increased considerably. The definitions of 'culture' would have increased significantly. Consequently, the exploration of how 'culture' is used by specific people for specific purposes in a specific context is a key task of intercultural communication research $[2, p .5]$. To find out what the underlying understanding of 'culture' is, I deal with the 'culture' entries on Russian
Language dictionaries, English Language dictionaries, and Chinese dictionaries.

From the Russian explanatory dictionaries, culture is defined in the following aspects: 1) the totality of human achievements of a nation in the industrial, social and spiritual spheres in a certain epoch. 2) The development and the development results of human achievements of a nation in the industrial, social and spiritual spheres in a certain epoch. 3) The preserve and diffuse of human achievements. 4) the knowledge, belief, art, morals, law, custom and any other capabilities and habits acquired by human being as a member of society. 5) Created by the human beings artificially, decided by the ideology of human beings. 6) The high level of human being's consciousness, the reflection of human being's implicit and explicit awareness and world viewpoints [3-5].

In Oxford Advanced Learner's English Dictionary, culture is defined as following: 1) art, literature, music and other intellectual expressions of a particular society or time. 2) The customs and beliefs, art, way of life and social organization of a country or group [6, p. 285].

In Collins Concise Dictionary, culture is interpreted in the following aspects: 1) the total of the inherited ideas, beliefs, values, and knowledge, which constitute 
the shared bases of social action. 2) The total range of activities and ideas of people. 3) A particular civilization at a particular period. 4) The artistic and social pursuits, expression and tastes valued by a society or class, meanwhile, the enlightenment or refinement resulting from these pursuits [7, p. 351].

In Cambridge Advanced Learner's Dictionary, culture is interpreted in the following aspects: 1) the way of life, especially the general customs and beliefs, of a particular group of people at a particular time. 2) Music, art, theatre, literature etc. 3) Describes someone who has a good education and knows a lot about art, music, literature, etc. [8, p. 302-303].

From the Chinese explanatory dictionaries, culture is defined in the following aspects: 1) civilized ruling, literal administration, enlightenment and cultivation. 2) Ability of understanding and using languages and the ability of applying book knowledge into life and social practices. 3) Broad sense of culture is defined from the perspective of the distinction between society and nature, which refers to the sum of both material wealth and spiritual wealth created in the process of human history. This kind of cultural understanding is also called the 'Great Culture' or 'Big Culture"; in a narrow sense, culture refers to social ideology and its appropriate regulations and organizations, which systematically and consciously reflects the economic forms and political systems. 4) Culture refers to general knowledge, including philology. 5) Archaeological terminology [9-11].

Explorations of multiculturalism, third cultures, hybridity and crossing are often conceived as challenges to dominant accounts of a uniform culture. However, as Holliday (1999) argues, these accounts still take the nation and(or) ethnicity as their point f departure. Holliday (1999) refers to these as 'big culture' and argues for a shift of focus to 'small culture', which he defines as 'relating to cohesive behavior in activities within any social grouping', for example, a 'company culture' or a 'family culture' $[12$, p. 214].

The obvious point is that, given the explanations of culture in Russian Language dictionaries, English Language dictionaries, and Chinese dictionaries, 'big culture' and 'small culture' are both covered. From the analysis above, we could conclude that culture is collections of material and spiritual wealth, created in the history of the practical activities of human society. Culture has the distinct characteristic of a team, a group, a region or a nation, which has been developed in a long term and it, is dynamic which keeps pace with the constant changing environment. Meanwhile, the development of one culture could not be separated or isolated from other cultures.

Given the state of connectedness of our world, no culture exists in isolation. 'culture' is in a constant state of flux and cross-fertilization. Given that each of us belongs to many cultures in this sense, and that all these combinations are slightly different, it is thus possible to argue that, in this sense, all communication is intercultural [12, p. 213-214]. Intercultural communication is the interaction of carriers of different cultures; however, human being is not the only bearer of culture.

Biologists and psychologists claim that some animals (in particular, anthropoid apes) are able to develop and transmit culture. Thus, a large population living animals are carriers of different cultures and the interaction of these groups can also be called intercultural communication. It is obviously that the theory of intercultural communication does not occupy the study of animal communication analysis. Meanwhile, it is more important to understand that intercultural communication is a very ancient phenomenon, which appeared simultaneously with the formation of what we call different cultures [13, p. 6-7]. Although people have involved in the intercultural communications since ancient time, however, the theory of intercultural communication as an independent scientific discipline arose in the middle of the 20th century.

Intercultural communication as the terminology was firstly mentioned by the American researchers G. Trager and E. Hall in their work "culture and communication" in 1954, which was a landmark in the history of cross-cultural communication research. Cross-cultural communication as a subject began to be taught in a number of universities in the USA in the 1960s. In Europe, the emergence of cross-cultural communication as an academic discipline took place later than in the United States, which was associated with the creation of the European Union. In this regard, the interests of scholars to cross-cultural communication problems have developed and increased.

Departments of cross-cultural communication were established during the period of the 1970s and 1980s in some Western European universities. Foreign language teachers in Russia realize that it is not enough to carry out effective communications with representatives of other cultures by knowing the foreign language. Thus, the theory of intercultural communication as a discipline was opened in Russian universities, which aimed to help individuals to be able to communicate with representatives of the studied language adequately and successfully [14, p. 6].

The theory of intercultural communication was firstly introduced into China in 1980s, which emphasized on the application of intercultural communication theories in foreign language teaching. The turning point of the development of intercultural 
communication theory was in 1995 by the work of Guan Shijie. In the $21^{\text {st }}$ century, the research scope of intercultural communication has extended widely and the general research directions could be divided into the following aspects: 1) intercultural communication and foreign language teaching; 2) intercultural communication and culture comparison; 3) intercultural communication and mass media; 4) intercultural management; 5) the cultivation of intercultural competence and intercultural training [15, p. 29].

The enhancement of intercultural communication competence is a guarantee of effective and successful intercultural communication. The intercultural communication competence contains four hierarchies: 1) global mentality; 2) cultural adaption; 3) knowledge; 4) communication management [16, p. 14-18].

Intercultural communication, as known cross-cultural and trans-cultural communication, indicates the exchange ideas, emotions and information by means of languages, words and body languages between people from different culture [17, p. 4]. A lot of concepts and theories have been elaborated, supported by numerous examples and cases drawn from real life settings, to provide further evidence about national cultural distinctions. Now, intercultural communication is incorporated into academic and professional management courses around the world [18, p. 145]. Intercultural communication serves as a lubricant, mitigating frictions, resolving conflicts, and improving working efficiency in international organizations [19, p. 9].

\section{An Unsuccessful Intercultural Communication Case Analysis}

March $8^{\text {th }}$ is an official public holiday for females of Russian federation to enjoy their special day and wait for their gifts. This beautiful spring holiday is customarily celebrated in the family circle with a festive meal and champagne. Men and women give flowers, postcards with poetry, chocolates, and other pleasant gifts to their mothers, wives, grandmothers, sisters and daughters. Some Russian females like to undertake all household duties on this day - starting with washing dishes and ending with cooking dinner and looking after children, so that women can enjoy a full day of rest [20].

According to a poll conducted by the leading Russian sociological company VCIOM in 2016, one third of Russians think March $8^{\text {th }}$ is the day full of warm feelings and excitement in contemporary Russia. In the result of the poll, some Russians think of it as a tradition (16\%) or an opportunity to make a pleasant surprise to women (15\%). The holiday is viewed as just an extra day off by $14 \%$ of Russians, while $10 \%$ of Russians associate it with gifts and flowers. The International Women's Day is a very special and important day for $70 \%$ of Russian federation, and only a few thinks it as waste of money ( $2 \%)$. Interestingly, Russian women often consider March $8^{\text {th }}$ a day of pleasant emotions, high spirits, and vivid impressions [21].

National Women's Day in Russia is not simply a holiday for women to celebrate but also to strengthen the female image of being powerful, graceful, diligent and innovative as well as warning the males that they should respect each woman and admit the women's progresses and contributions and show gratitude to women's sacrifices to the family, to their work, to their society and to their country.

Without identifying and comparing the cultural differences between China and Russia, the exchange Chinese students have an unsuccessful cross culturalcommunication experience in Russia on $7^{\text {th }}$, March 2017. A group of exchange students from China went to class as usual; they were shocked by what they had seen the moment as they set feet in the classroom. The classroom was well decorated, lots of snacks, soft drinks, cakes and cups were on the desk, and the teacher Catherine got well dressed. All the girls were surprised, when they received small gifts from their teacher at the beginning of the class. The teacher celebrated the International Women's Day in advance, because she would celebrate the festival with her family. When March $8^{\text {th }}$ came, the exchange students found that the females including children, and the old ladies were celebrating it. Then the exchange students realized that there exist cultural differences in cross culture communication.

\section{Interpretations of the word "woman" in Chinese linguoculture}

To reveal their pure attitudes towards International Women's Day, we conducted research among the exchange students of Zhejiang Ocean University who were born and grew up in China, who know Chinese culture and are influenced by this culture, were drawn to the experiment. In the experiment, 50 students participated in the test, $100 \%$ of them are females between the ages of 19 and 27, different faculties and fields of study (humanities, technical sciences, etc.). The order of the experiment: 1) select subjects; 2) ask them to write their attitudes towards the International Women's Day in the form of marks (from 1 to 5) (Table 1 and Fig. 1); 3) to explore the roots of objection or definite objection towards International Women's Day (Table 2 and Fig. 2).

Table 1

Attitudes towards the International Women's Day in the form of marks

(5: strongly agree ; 4: agree; 3 : indeterminacy; 2: objection; 1: definite objection)

\begin{tabular}{|c|c|c|c|c|c|}
\hline $\begin{array}{c}\text { International } \\
\text { Women's Day }\end{array}$ & $\begin{array}{c}5 \\
\text { strongly } \\
\text { agree }\end{array}$ & $\begin{array}{c}4 \\
\text { agree }\end{array}$ & $\begin{array}{c}3 \\
\text { indeter- } \\
\text { minacy }\end{array}$ & $\begin{array}{c}2 \\
\text { objection }\end{array}$ & $\begin{array}{c}1 \\
\text { definite } \\
\text { objection }\end{array}$ \\
\hline
\end{tabular}


Attitudes toward the International Women's Day

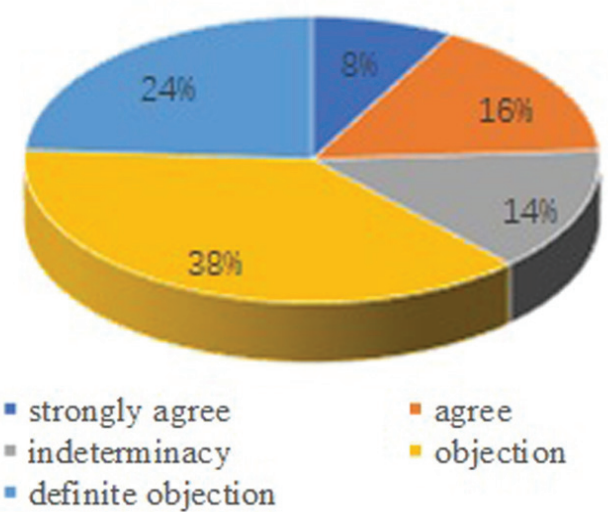

Fig. 1. Analysis of the questionnaires results (Chart 1)

Table 2

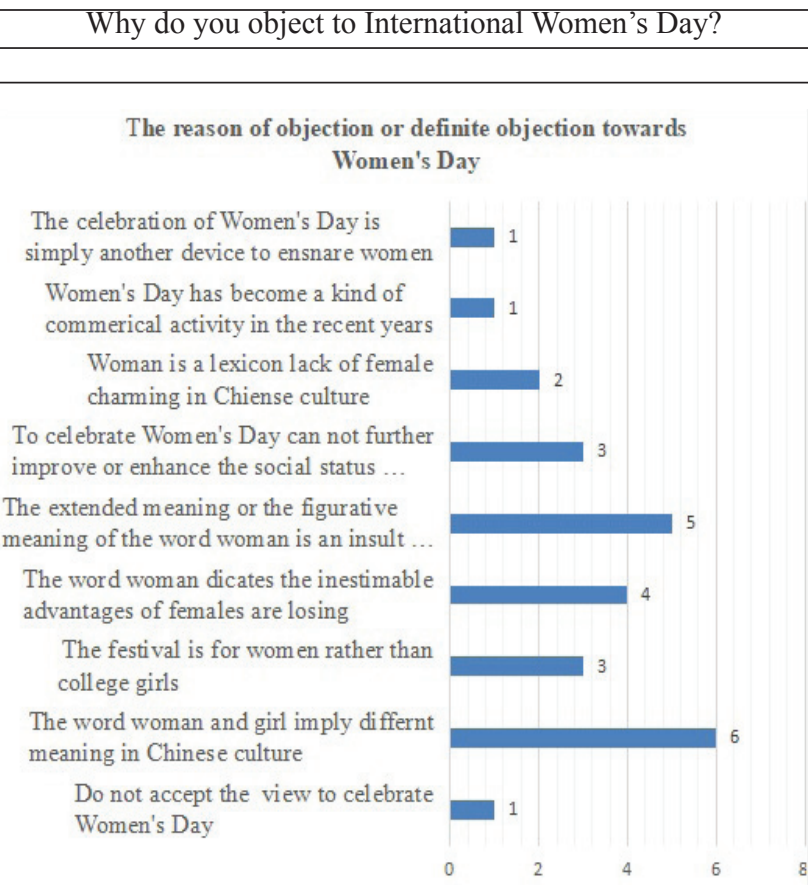

Fig. 2. Analysis of the questionnaires results (Chart 2)

\section{Compared with the word "woman", the word "girl" symbolizes the best years of a female in Chinese language context}

From Chinese explanatory dictionaries, the word "woman" has the following meanings: 1) an adult female human. 2) Female human in general. 3) In compounds. 4) A female worker, especially one who works with her hands. 5) Old-fashioned, a rude way of addressing a female person in an angry or important way. 6) Sometimes disapproving a wife or sexual partner. The word "girl" has the following meanings: 1) a female child, a female child or young person. 2) A daughter. 3) Sometimes offensive, a young woman. 4) Girls, used especially as a form address by women, a women's female friends. 5) Old girl, often offensive, an old woman, especially somebody's wife or mother.

From the analysis above, we could conclude that the word "girl" and "woman"symbolizes significantly different semantic fields (Fig. 3).

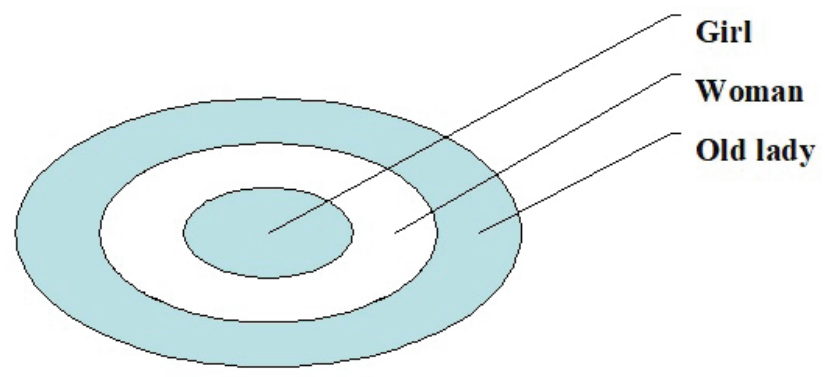

Fig. 3. Semantic fields of words "girl" and "woman"

In the "Classic of Poetry"1, the author used metaphors to describe the destiny of an abandoned woman. The author compared the heroin to a tree, when spring comes the leaves are green and lively, the hero fallen deep in love with her immediately. However, when autumn comes, the leaves turn yellow meaning that the heroin liked the yellow leaves, withering and wrinkling. Chinese poet $\mathrm{Du} \mathrm{Mu}^{2}$ gave brief accounts of beauty in his poem: "She is slender and graceful and not yet fourteen, like a cardamom at the tip of a new spray. When the spring wind unrolls the window screen, her face outshines those on the splendid three - mile way". By Du Mu's standards, the best age of a female is about 13-14 years old in the ancient Tang dynasty of China; they are like blossoming flowers scent and charming. In the poem of Liang Shaoren ${ }^{3}$, beautiful girls in the capital of Beijing look like jade; they are about 15 or 16 years old. By Liang Daoren's standards, the best age of a female is about 15-16 years old in the ancient Qing dynasty of China.

\section{The Word "Woman" Symbolizes Negative Images in Traditional Chinese Cultural Context}

There is no doubt that the culture's history affects individual perception and behavior and the way people relate to another culture. The word woman in Chinese cultural and people is always interpret social context as a cultural symbol of married female involving in family trivial affairs, being shiftless and sloppy, being old and useless and even taking the risk of being

\footnotetext{
1 "Classic of Poetry - 诗经》 (in Chinese) is the oldest existing collection of Chinese poetry, comprising 305 works dating from the 11 th to 7 th centuries $\mathrm{BC}$.

${ }^{2} \mathrm{Du} \mathrm{Mu}$ (Chinese: 杜牧; 803-852) one of the leading Chinese poets of the late Tang dynasty, who is best known for his lyrical and romantic quatrains.
}

${ }^{3}$ Liang ShaorenChinese: 梁绍壬;) Chinese poet in Qing dynasty. 
abandoned by husbands; or interpreted as sexual partners. Ironically, the creation of homeless, abandoned female images promoted the development of the traditional literature. A famous Chinese poet Bai Juyi ${ }^{1}$ in Tang dynasty in his poem "Song of a Pipa" Player gave an account of an eminent beautiful prostitute who got married to a merchant and was abandoned when she got old and stringy.

In the male domain world, the traditional Chinese females were subordinate to the females, which means that they should be obedient to their father before they get married, obedient to their husband when they get married and obedient to their son when their husbands died. Traditionally, the females' mental securities, and value judgement were attached to the males in the male domain society and the so-called traditions were handed down from generation to generation. Due to the long-term lack of self-cognition, spontaneity and self-consciousness in the male domain society, they think that International Women's Day couldn't further improve or enhance the social status, the long-rooted gender discrimination of the society haven't reduced, and the family roles of females haven't changed. In many cultures, there has been a fundamental change in the roles and images of women and men over the last fifty years.

In particular, women have realized that they have in general been discriminated against and their talents have been undervalued. In addition, they have fought back. However, women still remain a minority in leading positions of society, even if a substantial one, and women still generally earn less than men in the same position even if equally qualified [19, p. 39]. Nowadays China has entered the cultural transition period where the contemporary culture is going to take the place of traditional culture, and the national culture is facing the challenge and invasion of foreign culture. Under such circumstance, people have developed double - character. Conceptually, they show great interest in the new concepts, new ideology, and new communication pattern; meanwhile, they introspect the traditional culture, criticize the traditional culture and refuse the traditional culture. However, unconsciously the traditional national culture convinces them to be accustomed to enduring the existing cultural stereotypes and behaviors.

\section{The Word "Woman" Reflects the Cultural Discrimination on the Aging Female in China}

People would like to put the word "old" before their family name like old Zhang or old Li, even they call foreigners "Lao Wai", call teachers (Lao Shi). While sometimes if we put old before the words, the essences of their meaning are totally different. The old man means that the man is old and useless; the old fool means that no fool like an old fool and as for the old to die is better than to preserve the life. Lacking in youth vigor means that when people get old, their vigor get lost. When people get old, they always flaunt their seniority. Robbing the cradle means that the old get married with the younger one. In Chinese culture, if we put old before some Chinese words for females, the essences of their meaning are insulting them: 1) the old lady also means the lady is weak, dirty, and trouble makers. 2) The lady who has been 30 is old but still beautiful (no spring chicken, an elderly woman of fading charms). 3) The maidservant. 4) A woman is running a brothel.

\section{Conclusion}

Globalization inevitably influences the concept and ideology of the whole world. Under such circumstances, effective intercultural communications act as bridges to link different cultures of the world. The failure case of the exchange students demonstrated that effective intercultural communication involves the grasp of cultural traditions, customs, beliefs, and cultural inhibitions that we are communicating with, the awareness of cultural assumptions, cultural differences, cultural identities, stereotypes, as well as the cultural dynamics. The core of intercultural communication is to establish and understand how people from different cultures communicate with each other. To share ideas, experiences, and different perspectives and perception with local people, we should have a better understanding of culture differences.

\section{References}

1. Martin J. N., Nakayama T. K. Intercultural communication in contexts. 5th ed. Boston, Higher Education Press, 2010. $500 \mathrm{p}$.

2. Piller I. Intercultural Communication: A critical Introduction. Edinburgh, Edinburgh University Press, 2017. 225 p.

3. Ozhegov S. I. Tolkovyy slovar' russkogo yazyka [Explanatory dictionary of the Russian language]. Moscow, Peace and Education Publ., 2012, p. 1376 (in Russian).

4. Matveyeva T. V. Polnyy slovar' lingvisiticheskikh terminov [Complete dictionary of linguistic terms]. Rostov-on-Don, Feniks Publ., 2010. 560 p (in Russian).

\footnotetext{
${ }^{1}$ Bai Juyi (also Chinese: 白居易; 772-846) was a renowned Chinese poet and Tang dynasty government official. Many of his poems concern his career or observations made about everyday life, including as governor of three different provinces.
} 
5. Stepanov Y. S. Konstanty. Slovar' russkoy kul 'tury [Constants. Dictionary of Russian culture]. Moscow, Academic Project Press, 2001. 990 p. (in Russian).

6. Oxford Advanced Learner's English Dictionary of Current English. AS Hornby, Fifth edition Editor Jonathan Crowther. Oxford, Oxford University Press, 1999. 1428 p.

7. Collins Concise Dictionary. Glasgow, Harper Collins Publishers, 2000. 1740 p.

8. Cambridge Advanced Learner's Dictionary. Cambridge, Cambridge University Press, 2005. 1572 p.

9. Cihai standard dictionary. Shanghai, Shanghai Lexicographical Publishing House, 1979. 4914 p. (in Chinese).

10. Ciyuan dictionary. Beijing, the Commercial Press, 1991. 1739. p. (in Chinese).

11. Hanyu dictionary (Volume 6). Shanghai, Publishing House of an Unabridged Chinese Dictionary, 1990. 1619 p. (in Chinese).

12. Piller I. Linguistics and Intercultural Communication. Arizona, Language and Linguistic Compass (1/3), 2007. Pp. $208-226$.

13. Guzikova M. O., Fofanova P. Y. Osnovy teorii mezhkul'turnoy kommunikatsii [Basic theories of intercultural communication]. Ekaterinburg, Publishing house of Ural University, 2015. 124 p. (in Russian).

14. Frik T. B. Osnovy teorii mezhkul'turnoy kommunikatsii [Basic theories of intercultural communication]. Tomsk, Tomsk Polytechnic University Publ., 2013. 100 p. (in Russian).

15. Hu W. China's intercultural communication viewed from the perspective of disciplinary development. Journal of Foreign Languages, 2010, vol. 33, no. 6, pp. 28-32.

16. Yang Y., Zhuang E. Framework construction of intercultural communication competence in foreign language teaching. Journal of Foreign Language World, 2007, no. 4 (121), pp. 13-43.

17. Yuan W. Intercultural communication and conflict between American and Chinese colleagues in China-based multinational organizations. Diss. doct. sci., 2006. 5 p. (in Chinese).

18. Tsibulya N. B. Razlichnye aspekty mezhkul'turnoy kommunikatsii [Various Aspects of Intercultural Communication]. Magazine of Moscow State Linguistic University, 2014, vol. 3 (689), pp. 145-146 (in Russian).

19. Yu Li. Cross-Cultural Communication within American and Chinese Colleagues in Multinational Organization. Volume: 2010 Proceeding of 68th New York State Communication Association. 131 p.

20. March 8: International Women's Day - Russian Holidays. http://masterrussian.com/russianculture/womens_day_march8.htm.

21. Huber-Kriegler M., Lázár I. and Strange J. Mirrors and windows. Strasbourg, Council of Europe Publishing, 2003.101 p.

Liu Chaojie, Candidate of Philolody Science, Secretary of International Affairs Department, Zhejiang Ocean University (Haida NanLu street, 1, Zhoushan, China, 316022).E-mail: liuwillam666888@163.com

Zhong Weiliang, Associate Researcher, Deputy Director of International Affairs Department, Zhejiang Ocean University (Haida NanLu street, 1, Zhoushan, China, 316022).E-mail: 524782938@qq.com

Материал поступил в редакцию 20.05.2020.

\section{DOI 10.23951/1609-624X-2020-5-65-71}

\section{ИНТЕРПРЕТАЦИИ СЛОВА «ЖЕНЩИНА» В КИТАЙСКОМ ЯЗЫКЕ (НА ОСНОВЕ АНАЛИЗА НЕУДАЧНЫХ СЛУЧАЕВ МЕЖКУЛЬТУРНОЙ КОММУНИКАЦИИ)}

\section{Лю Чаоцзе, Чжун Вэйлян}

Чжэизянский океанический университет, Китай

Введение. Общепризнано, что коммуникация - это поведенческий процесс, задача которого состоит в том, чтобы помочь различным поведенческим агентам достичь двухстороннего информационного потока через различные носители, сформировать восприятие поведения агентов и добиться определенной цели. Общение может сблизить людей, а культурные различия - разделить их. Люди довольно часто игнорируют социальные и культурные факторы в межкультурной коммуникации, что может привести к нарушению коммуникации.

Цель статьи - определить интерпретации слова «женщина» в китайском языке.

Материал и методы. Использованы многочисленные теоретические работы по межкультурной коммуникации, которые заложили прочную основу для интерпретации базового понятия, а также китайские и английские толковые словари для интерпретации семантического значения слова «женщина». На основе анализа кейсов выявляются семантические различия слова «женщина» в китайском и русском языках и указывается на негативное отношение китайских студентов к семантическому значению данного слова. Кроме того, проведено исследование среди студентов по обмену из Чжэцзянского океанического университета с целью выявления скрытых причин, вызвавших негативное отношение к семантическому значению слова «женщина». 
Результаты и обсуждение. На основе анализа неудачного опыта межкультурной коммуникации студентов по обмену из Китая эксплицитно раскрываются семантические значения, включающие расширенное и образное значение слова «женщина» в контексте китайского языка, а также исследуются корни формирования существующих когнитивных семантических значений.

Заключение. Глобализация неизбежно влияет на идеологию всего мира. В настоящее время Китай вступил в переходный период, когда современная культура должна занять место традиционной культуры, а национальная культура сталкивается с вызовом и вторжением иностранной культуры.

Ключевые слова: культура, культурные различия, межкультурная коммуникация, слово «женщина», семантические значения.

\section{Список литературы}

1. Martin J. N., Nakayama T. K. Intercultural communication in contexts. 5th ed. Boston: Higher Education Press, 2010. $500 \mathrm{p}$.

2. Piller I. Intercultural Communication: A critical Introduction. Edinburgh: Edinburgh University Press, 2017. 225 p.

3. Ожегов С. И. Толковый словарь русского языка. М.: Мир и образование, 2012. 1376 с.

4. Матвеева Т. В. Полный словарь лингвистических терминов. Ростов н/Д: Феникс Пресс, 2010. 560 с.

5. Степанов Ю. С. Константы. Словарь русской культуры. М.: Академический Проект Пресс, 2001. 990 с.

6. Oxford Advanced Learner's English Dictionary of Current English. AS Hornby. 5th ed. / ed. J. Crowther. Oxford: Oxford University Press, 1999. 1428 p.

7. Collins Concise Dictionary. Glasgow: Harper Collins Publishers, 2000. 1740 p.

8. Cambridge Advanced Learner's Dictionary. Cambridge: Cambridge University Press, 2005. 1572 p.

9. 辞海标准词典. 上海: 上海辞书出版社, 1979. 4914 页. Стандартный словарь Цихай. Шанхай: Шанхайское лексикографическое изд-во, 1979. $4914 \mathrm{c.}$

10. 词源词典. 北京: 商务印书馆, 1991. 1739页. Словарь Циюань. Пекин: Коммерческое изд-во, 1991. 1739 с.

11. 汉语词典 (第6卷). 上海: 汉语大词典出版社, 1990. 1619页. Словарь Ханью. Шанхай: Изд-во полного китайского словаря, 1990. T. 6. 1619 c.

12. Piller I. Linguistics and Intercultural Communication // Arizona, Language and Linguistic Compass. 2007. № 1/3. P. $208-226$.

13. Гузикова М. О., Фофанова П. Ю. Основы теории межкультурной коммуникации. Екатеринбург: Изд-во Уральского ун-та, 2015. $124 \mathrm{c}$.

14. Фрик Т. Б. Основы теории межкультурной коммуникации. Томск: Изд-во Томского политехн. ун-та, 2013. 100 с.

15. Hu W. China's intercultural communication viewed from the perspective of disciplinary development // Journal of Foreign Languages. 2010. Vol. 33, № 6. P. 28-32.

16. Yang Y., Zhuang E. Framework construction of intercultural communication competence in foreign language teaching // Journal of Foreign Language World. 2007. № 4 (General Serial № 121). P. 13-43.

17. 吴元任. 在中国的跨国组织中的中美同事之间的跨文化交流与冲突 (博士论文), 2006. 5 页. Юань У. Межкультурная коммуникация и конфликт между американскими и китайскими коллегами в базирующихся в Китае многонациональных организациях: докт. дис. 2006. С. 5.

18. Цибуля Н. Б. Различные аспекты межкультурной коммуникации // Журнал Московского государственного лингвистического университета. 2014. Т. 3 (689). С. 145-146.

19. Yu Li. Cross-Cultural Communication within American and Chinese Colleagues in Multinational Organization: Proceeding of $68^{\text {th }}$ New York State Communication Association. 2010. 131 p.

20. March 8: International Women's Day - Russian Holidays. URL: http://masterrussian.com/russianculture/womens_day_march8. $\mathrm{htm}$

21. Huber-Kriegler M., Lázár I., Strange J. Mirrors and windows. Strasbourg: Council of Europe Publishing, 2003.101 p.

Лю Чаоцзе, кандидат филологических наук, секретарь Департамента международных отношений, Чжэцзянский океанический университет (ул. Хайда Наньлу, 1, Чжоушань, 316022, Китай). E-mail: liuwillam666888@163.com

Чжун Вэйлян, младший научный сотрудник, заместитель директора Департамента международных отношений, Чжэцзянский океанический университет (ул. Хайда Наньлу, 1, Чжоушань, 316022, Китай).

E-mail: 524782938@qq.com 